\title{
Use of ICT in the training of legal skills
}

\author{
Citation for published version (APA):
}

Nadolski, R., \& Wöretshofer, J. (2005). Use of ICT in the training of legal skills. The Law Teacher, 39(1), $29-42$. https://doi.org/10.1080/03069400.2005.9993169

\section{DOI:}

10.1080/03069400.2005.9993169

Document status and date:

Published: 01/01/2005

Document Version:

Peer reviewed version

\section{Document license:}

\section{BY-NC-ND}

\section{Please check the document version of this publication:}

- A submitted manuscript is the version of the article upon submission and before peer-review. There can be important differences between the submitted version and the official published version of record. People interested in the research are advised to contact the author for the final version of the publication, or visit the DOI to the publisher's website.

- The final author version and the galley proof are versions of the publication after peer review.

- The final published version features the final layout of the paper including the volume, issue and page numbers.

Link to publication

\section{General rights}

Copyright and moral rights for the publications made accessible in the public portal are retained by the authors and/or other copyright owners and it is a condition of accessing publications that users recognise and abide by the legal requirements associated with these rights.

- Users may download and print one copy of any publication from the public portal for the purpose of private study or research.

- You may not further distribute the material or use it for any profit-making activity or commercial gain

- You may freely distribute the URL identifying the publication in the public portal.

If the publication is distributed under the terms of Article 25fa of the Dutch Copyright Act, indicated by the "Taverne" license above, please follow below link for the End User Agreement:

https://www.ou.nl/taverne-agreement

Take down policy

If you believe that this document breaches copyright please contact us at:

pure-support@ou.nl

providing details and we will investigate your claim.

Downloaded from https://research.ou.nl/ on date: 26 Apr. 2023 


\section{century}

thoughts about how lective practice in an orogramme of study. ific curriculum of the or those interested in 1 practice.

ictice has a significant even if, to date, it snvironment. In "The ucation", Judge Jack ice in the context of ontinuing debate on

can and should be lbran wrote: "Judges igths and weaknesses tatement not so much e professionalism of bout the ways judges

this can be achieved.

$I$ in the now growing evise ways in which er [...] they have $s$ as they begin, and

professional practice $a$ more by integrating ve heart of the online

es, Emeritus Professor and dicial Education," fourmal of es: Adopting an Holistic discusses the inportance of could be used in judicial

\section{USE OF ICT IN THE TRAINING OF LEGAL SKILLS}

\author{
By ROB NADOLSKI and JÜRGEN WÖRETSHOFER*
}

\section{Introduction}

FLEXIBLE PROBLEM-SOLVING behaviour based upon applying complex cognitive skills is now regarded as a desirable attribute of law graduates. Acquiring these complex cognitive skills can only be accomplished through a complex lenrning process where knowledge, skills, and attitudes are acquired and integrated and where these are coordinated during task execution. Only then can we acquire those complex skills that aim at transfer of what is learned in law school to work settings. The challenging question for legal education is, how can we help law students acquire these complex cognitive skills? And an inferred question is: how can this be done with minimum expenditure? Short answers to those questions respectively may be to use a situated learning paradigm, and use ICT. We shall examine this in more detail below.

\section{Situated learning paradigm and support}

Modern instructional theories focus increasingly on authentic learning tasks based on real-life tasks as the paramount condition for learning. ${ }^{1}$ A considerable risk with using such authentic tasks is that they are often too difficult for novice learners to deal with as a whole. A common solution for this problem is to provide support that segments the problem-solving process of whole learning tasks into smaller phases and helps learners to carry out those phases. Providing support is inextricably bound up with learning and can be made operational via process worksheets, "driving" questions, and feedback. ${ }^{2}$ Process woorksheets, ${ }^{3}$ offer a way to help learners understand the framework, and guide them through the phases in the problem-solving process of the whole learning task. Focused questions are open questions given at the start of a phase and guide learners in how to carry out a phase, for instance, by suggesting relevant procedures and principles, by activating relevant prior knowledge, and by referring

Educational Technology Expertise Centre and Faculty of Law, Open University of the Netherlands.

1 M. D. Merrill, First principles of instruction, Ednotional Tichnolog, Resench and Dextopment, 50, 43-59, (2(02); C.M. Reigeluth (ed.), Instructional tesign theoric's ind modds: A ncto parudiom of instructional theory, Vol. 2 (1999), Mahwah, NJ: Lawrence Erlbaum Associates; J.J.G. van Merriënbcer and P.A. Kirschner, Three worlds of instructional designi State of the art and future directions, listructionnl Scichce, 29, 429-441, (2001).

2 For example, E. H. Mory, Feedback research, in Houthock of reserurch for ectucatimum commmications and tichmolog'm edited by D.H. Jonassen, New York: Macmillan Library
Reference (1996).

3 J. J. G. van Merriënboer, Truming compler cognitior skills, Englewood Cliffs. NJ: Educational Technologv Publications (1997). 




th questions combined directed learning is

rience for instructional traditional universities :ance universities such uch facilities and are llations or multimedia ed electronic learning ztice to students for lar disease, selecting a ause mental overload urt. ${ }^{5}$ These practicals he cognitive schemata

its mastery involves ; and not simply the esearchers ${ }^{6}$ agree that $\mathrm{gh}$ the use of realistic on, an environment to $y$ of task execution. $n$ only be expected in the necessary schema

for future leurning, Utrecht/ on, Teading, questioning and Naidu and R.M. Bernard, icept mapping and inserted Harder, R.C. Callahan, D.P instruction, 4th ed., Toronto nce learning, London: Kogan

3. K. Hummel, A model for media practicals. Etucationa and PB. Sloep, The Virtual environment in distance

environments: Foundations, " therrises and models: A noi Lawrence Erlbaum (1999), In C. M. Reigeluth (ed.), th thery Vol. 2, pp. 215-239, nstruction for constructivist 'Modis: A ncill paratigll of baum (1999); M. D. Merrili, toelopment, $5043-59(2002)$; ts in complex learning: Do and Instrution, 8, 117-129 acquisition, ${ }^{7}$ where there is much variability in practice, ${ }^{8}$ and where there is stimulation of mindful abstraction. "Transfer-oriented learning is aimed at the mindful abstraction from concrete learning experiences to be effectively used in a variety of previously unencountered settings. Through support, complex learning tasks come within reach of learners' capabilities. Such support is embedded within multimedia practicals.

\section{Situated learning paradigm revisited for face-to-face educational institutions}

In the past, it has been distance universities who have been traditionally forced to implement the "situated learning paradigm" in ICT settings. More recently this approach has also been followed by other institutions in higher education because of the cost of face-to-face tutoring. Historically, such institutions have been reluctant to adopt this approach, and there are a number of reasons for this: the technical infrastructure was missing, the potential educational value was not fully apparent and funding ICT projects was always going to be problematic. In addition, ICT often disrupts settled patterns of teaching and learning. What is required to achieve the shift to ICT settings is a coherent educational strategy to develop and use ICT programs, and a critical mass of ICT programs to induce broader use and acceptance.

\section{Hypotheses of the case study}

The present study was conducted in an ecologically valid setting ${ }^{10}$ and employs a randomised design to examine the effects of support (present, absent) on the performing of legal interviewing tasks and on the efficiency of that performance. The first hypothesis was that students solving a legal interviewing task with support will show higher performance and be more efficient learners than students withdrawn from support. The second hypothesis was that universities' students will be more efficient learners than college students because of their differences in academic skills.

7 R. J. Spiro, R. L. Coulson, I. J. Feltovich and D. K. Anderson. Cognition flexibility theory: Adimced knowlidge taquisition in ill-strnctured domains (Tech. Rep. No. 441). Champaign, IL University of Illinois, Center for the Study of Reading (1958).

8 F Paas, and J. J. G. van Merriénboer. Variability of worked examples and transfer of geometrical problem solving skills: A cognitive load approach. Journul of Educationul Psychologil 86, 122-133 (1994) 9 D. N. Perkins, and G. Salomon. Are cognitive skills context-bound? Edncational kirstarcler, 18 ,
1t-25 (1989).

10 An ecologically valid setting enables participants to work with realistic tasks in realistic settings, but has, in comparison to a lab-experiment, the disadvantage that not all the actions of participants are monitored during the experiment. In our case, conducting a lab-experiment was clearly out of the question due to practical reasons. We have conducted some pilot

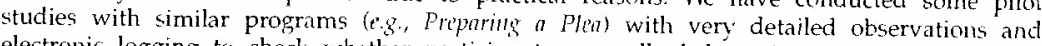
electronic logging to check whether participants generally behave in an expected manner. From these pilot studies participants general behaviour is known, and this is in accordance with the expectations for the current study. 
Task efficiency is defined as task performance in relation to perceived mental effort. Although efficiency can be operationalised in many different ways, ${ }^{11}$ higher efficiency always indicates equivalent results with lower investments, higher results with the same investments, or, ideally, higher results with lower investments. Perceived mental effort is a good indicator of how mentally demanding a task is. ${ }^{12}$ For example, if two students reach the same performance level, but the second student reports a higher level of mental effort, then the first student is said to be more efficient.

In this study, "prior knowledge" refers to prior legal interviewing skills. These skills might be influenced by prior domain knowledge with respect to Law and by academic skills. The randomised set-up of the present study and the provided information during the preparation stage of the legal interviews rule out possible effects of prior domain knowledge with respect to Law. Although we expected that participants would not have any relevant prior knowledge with respect to legal interviewing techniques, we collected some additional data to check this.

\section{Content of Legally Speaking}

Legally Speaking consisted of a textbook and a competency-based practical on CD ROM. ${ }^{13}$ The goal of the practical was to introduce law students as well as students of social work services to performance of a legal interview. Students received training on interview skills using three tasks (fact-finding, legal advice, and an interview where bad news needed to be imparted to the client). In Legally Speaking the learner is a trainee in a virtual law firm. The trainee was given a general introduction to legal interviews, in which supportive information and support tools were provided.

Supportive information is helpful to the learning and execution of problem-solving aspects of legal conversation tasks (e.g., providing a method for preparing a legal interview, segmented in various steps). The support tools for the general introduction include examples of lawyers conducting legal interviews and an "interview checker" to observe and analyse these examples.

During the general introduction, the trainee receives several assignments to guide the study of general interviewing theory ${ }^{14}$ as well as support from

$11 \mathrm{~S}$. Kalyuga, P. Chandler and $J$. Sweller levels of expertise and instructional design, Humun Factors, 40, 1-17 (1998); J. J. G. van Merriënboer, J. G. Schuurman, M. B. M. de Croock and F. Paas, Redirecting learners' attention during training: Effects on cognitive load, transfer test and training efficiency, Learning and Instruction, 12, 11-37 (2002).

12 For an overview of studies, see F. Paas, F, J. E. Tuovinen, H. Tabbers and P. W. M. van Gerven, Cognitive load measurement as a means to advance cognitive load theory, Edncational Psycholoyist, 381 1). 63-71 (2003).

13 J. Woretshofer, R. Verkijk, A. M. A. G. Starren-Weijenberg, R. A. M. Quanjel-Schreurs, M. Verdaasdonk, R. Kerkhoven, J. Daniels, W. M. J. Kerstjens, R. J. Nadolski, A. Slootmaker, M. H. L. S. Vos and J. Storm, Legilly Spenking IJuridisch Gesproken] (version 1.0) [multimedia CDROMI, Litrecht, The Netherlands: Dioitale Universiteit (2004).

14 Our approach to this is very practical. We do not intend to oblige the student to work within one specific theory of interviewing. The theory offered to students is derived from the a senior (virtual) er use of standard off: such as experts' of backgrounds of diffe consult experts. Aft legal interviews for information that is (e.g, carrying out contains bad news) related to the interv tool for practising, feedback on a detail

Supportive inforn section devoted to $t]$ a method for prepar information is also $\mathrm{i}$. up into segments (i.c office. As support feedback for each pl univocal answers, $t$ feedback supports se

Our experiment $w$ The participants in th the aforementioned $c$ needed to carry out ( withdrawn from sup two case files on pap. legal interviews. All working on the tasks. same theory (i.e., sup] withdrawn from inte learning environmen on interviewing prep. and "interview check the multimedia prac legal interviews outs

experience of Dutch 1 However, as the prevail lawyers is client-centre

15 S. Kalyuga, P. Chandle Fitcols, 40, 1-17 (1998); Paas, Redirecting learn and training efficiency,

10 For an overview of ctic Cognitive load measut Frychologist, 38(1), b3,.,1

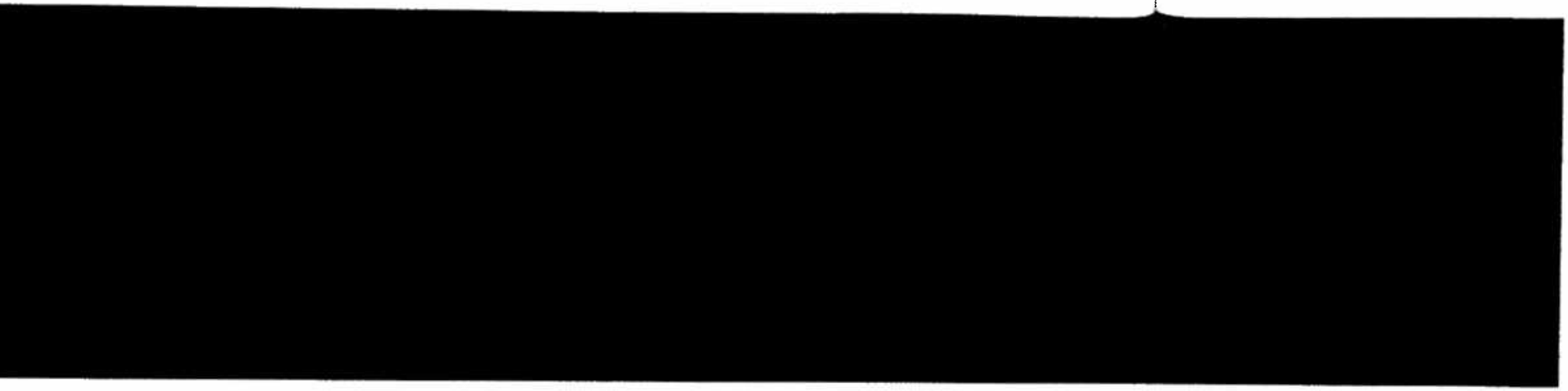




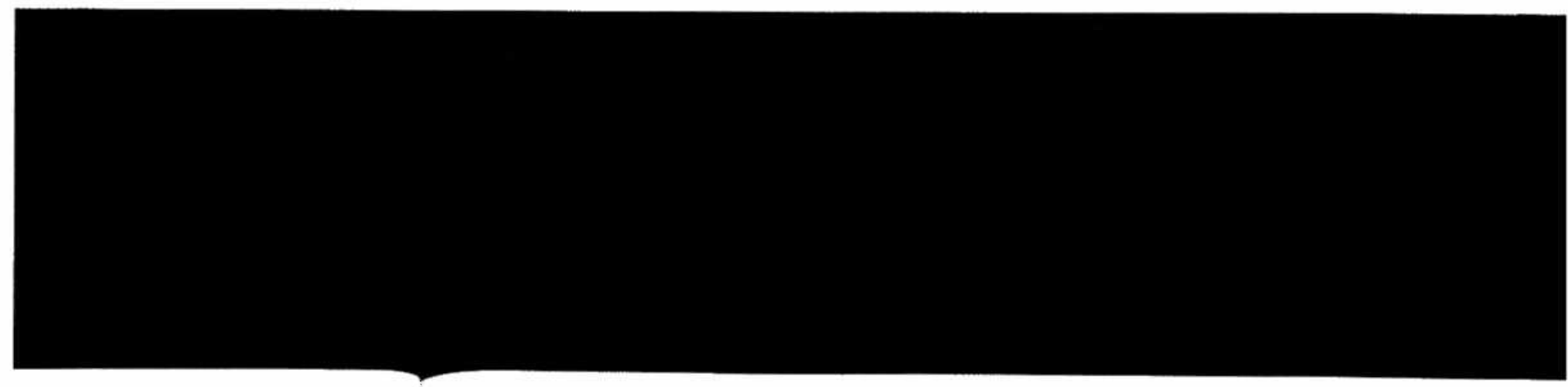

relation to perceived sed in many different it results with lower its, or, ideally, higher rt is a good indicator if two students reach reports a higher level re efficient.

;al interviewing skills. towledge with respect $p$ of the present study on stage of the legal lowledge with respect would not have any ewing techniques, we

etency-based practical iduce law students as :e of a legal interview. ree tasks (fact-finding, led to be imparted to in a virtual law firm. I interviews, in which ed.

ng and execution of is (e.g., providing a $\mathrm{n}$ various steps). The examples of lawyers "ker" to observe and

ss several assignments well as support from

instructional design, Hummut M. B. M. de Croock and F cognitive load, transfer test rs and P. W. M. van Gerven, e load theory, Eluational 4. M. Quanjel-Schreurs, M. tolski, A. Slontmaker, M. H. rsion 1.0) Imultimedia CD a senior (virtual) employee of this firm, the coach. The trainee can make use of standard office equipment and can visit other places in the firm, such as experts' offices. The trainee can, for example, study the legal backgrounds of different cases in a file cabinet, make electronic notes, and consult experts. After this general introduction, the trainee must prepare legal interviews for various cases (i.e., whole tasks), receives the supportive information that is more specifically related to a certain interview model (e.g., carrying out fact-finding, offering legal advice, an interview that contains bad news), and uses support tools that are more specifically related to the interviews to be prepared (e.g., an "interview simulator," a tool for practising/simulating an prepared interview with embedded feedback on a detailed level as well as on a global level). ${ }^{15}$

Supportive information in this course consists of a general section and a section devoted to the specific three interview models, which also contains a method for preparing a legal interview, segmented in various steps. This information is also included in the Textbook of the material. Tasks are split up into segments (i.e., phases). The case files are available within a (virtual) office. As support mechanisms, the coach provides assignments with feedback for each phase in the whole task. As the assignments do not have univocal answers, the feedback typically represents expert model(s). The feedback supports self-reflection by students. ${ }^{16}$

Our experiment was restricted to the tasks of fact-finding and legal advice. The participants in the "support" condition or experimental group received all the aforementioned course materials for both types of interview that students needed to carry out (fact-finding, and offering legal advice). The participants withdrawn from support (the control group), received only the Textbook, the two case files on paper, and a CD-ROM with examples of lawyers conducting legal interviews. All materials were kept available to participants while working on the tasks. In fact, the participants in the control group received the same theory (i.e., supportive information) as the experimental group, but were withdrawn from interactions that are typically possible in well-designed ICT learning environments (c.g., feedback on theory-based assignments, feedback on interviewing preparation; and support tools such as "interview simulator" and "interview checker"). Such an ICT learning environment was provided by the multimedia practical. Finally, the participants conducted the prepared legal interviews outside the multimedia practical. Final performance on the

experience of Dutch lawyers who function as teachers and practitioners in this subject However, as the prevailing theory in the Netherlands in teaching legal interview techniques to lawyers is client-centred intervieving, one could say that this is also prevalent in our theory:

15 S. Kalyuga, P. Chandler and J. Sweller, Levels of expertise and instructional design. Hmman Fnctors, 40,1-17 (1998); ). 1. G. van Merriénboer, I. G. Schuurman, M. B. M. de Crouck and F Paas, Redirecting learners' attention during training: Effects on cognitive load, transfer test and training efficiency, torming nnd listruction, 12, 11-37 (2002)

16 For an overview of studies, see F. Paas, I. E. Tuovinen, H. Tabbers and P. W. M. van Gerven, Cognitive load measurement as a means to advance cognitive load theory. Edmontionol
Poydholorist. $38(1), 03-71(2003)$. 
whole learning task (i.e., the legal interviews) outside the multimedia practical was considered proof of skill acquisition. ${ }^{17}$

\section{Method}

\section{Participants}

Twenty eight (21 female, 7 male; mean age $=26.6$ years, $\mathrm{SD}=7.3, \mathrm{Min}=18$, Max =43) of the 30 students from three Dutch universities (all reading for a Bachelor of Laws degree) and one Dutch college (field-oriented study for social workers) completed the experiment. At their enrolment in the institutions, they were randomly assigned to either the experimental group (who were given learning support in their preparation for a legal interview $(n=21)$ or to the control group, who were given no support in their preparation for a legal interview $(n=7)$. None of the participants had any prior legal interviewing experience. Two participants (one in each group) did not finish the course due to personal reasons. ${ }^{18}$

\section{Measurement instruments}

Background questionnaire. A background questionnaire gathered data on age, gender, attitude towards learning via computers, computer literacy, and legal interviewing experience. ${ }^{19}$

Performance instrument for fact finding intervicw. An instrument (16-pointscale) was used to measure the performance results of participants' fact-finding interview (e.g., client introduction, elicitation of facts and structuring of facts, built on a relationship based on mutual trust). The instrument proved to be reliable and content-valid (Spearman's rho $=0.7, p<0.01$, Cohen's Kappa $=0.6$ ).

Performance instrument for legal advice interview. An instrument (15-pointscale) was used to measure the performance results of participants' legal advice interview (e.g., client introduction, presentation of alternatives, recognition of and coping with, resistance). Several items were similar to those mentioned in the former instrument. The instrument also proved to be reliable and content-valid (Spearman's rho $=0.8, \quad p<0.01$, Cohens Kappa $=0.6)^{20}$

17 See, e.g., F. J. R. C. Dochy, Assessnent of prior knowledge as a deternimant for future lonrning. Utrecht/London: LEMMA, Jessica Kingsley (1992).

18 See N. Karweit, Time-on-task reconsidered: Synthesis of research on time and learning, Educational leadership: Jownt of the Associntion for Superision and Currioulum Dowelopment, 41 (1984), 32-35; W. Admiraal, $\dot{\mathrm{T}}$. Wubbels and A. Pilot, College teaching in legal education: Teaching method, students' time-on-task, and achievement, Research in Higher Ednontion, 40, $687-704(1999)$

19 J. M. Keller, Motivational design of instruction. In C.M. Reigeluth (Ed.), Instructionalinesign theories and models: An overvien of their current status, pp. 383-434, Hillsdale, NJ: Lawrence ErlbaumKeller (1983).

20 J. Woretshofer, R. Verkijk, A. M. A. C. Starren-Weijenberg, R. A. M. Quanjel-Schreurs, M. Verdaasdonk, R. Kerkhoven, J. Daniels, W. M. J. Kerstiens, R. J. Nadolski, A. Slootmaker, V. H. L. S. Vos and J. Storm, Legully speaking UJuridisch gesproken] (version 1.0) [multimedia CDROM]. Utrecht, The Netherlands: Digitale Universiteit (2004).
Instrument for time on on a pre-structured $t$ time and end time multiples of five min

Mental effort rating s both legal interview measure the perceive

Motivation rating $\mathrm{SCA}$ for both legal interv Examples of items: task was interesting best possible solutior

Content complexity ra complexity of the co advice interview on

\section{Procedure}

Prospective participi involved in the $\mathrm{d} \epsilon$ materials (e.g., learr estimated study load requirements, privac participants before participants were asl For practical reasons the study, primarily distribution of parti budget limitations. A decision criterion. : randomly assigned required to work i participants were Participants working to work phase-by-p skipping consecutive such participants di maximum learner $\mathrm{cc}$ when to consult ph. assignment in a phas

After six weeks required to carry ou slots (fact-finding, le legal interviews took result, the participar

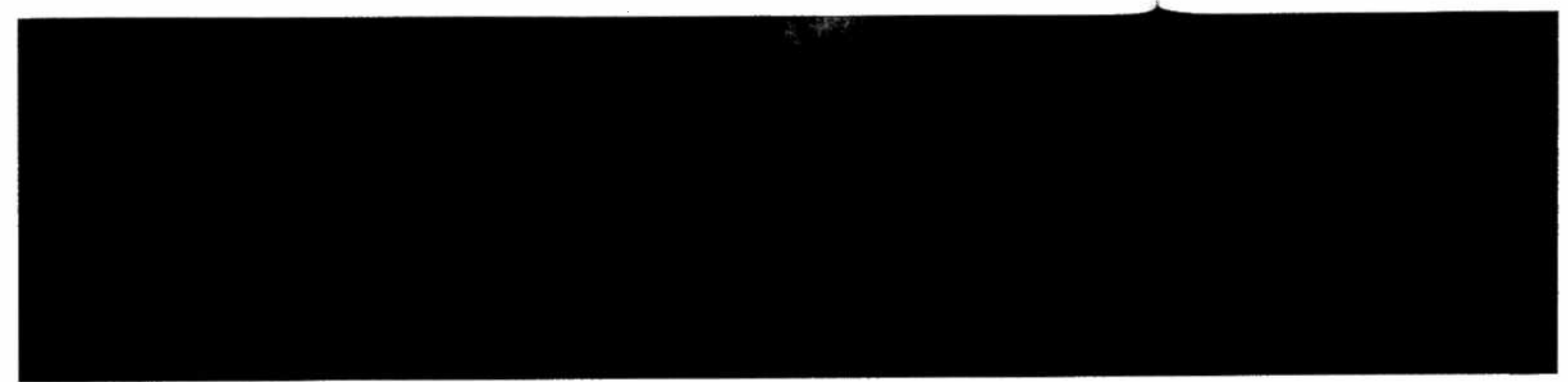


multimedia practical

; $\mathrm{SD}=7.3, \mathrm{Min}=18$ ties (all reading for a d-oriented study for $r$ enrolment in the experimental group for a legal interview no support in their participants had any one in each group )

athered data on age, nputer literacy, and

iment (16-pointscale) icipants' fact-finding and structuring of e instrument proved 7, $p<0.01$, Cohen's

ment (15-pointscale) cipants' legal advice matives, recognition re similar to those also proved to be $p<0.01$, Cohens

ratimut for titure lemrame

$h$ on time and leaming inriculumi Detelopment. 41 whing in legal education It in Highter Entucotion, 40

(Fd), lustrutionml-tesirn Hillsdale. N]: Laivrence

M. Quarijel-Schreurs, $\mathrm{V}$ Aski, A. Slootmaker, M. H. ion 1.0) [nultimedia CD
Instrument for time on task. Participants reported time on task for each phase on a pre-structured time sheet. They were instructed to note down the start time and end time for each phase and to note down the spent time in multiples of five minutes.

Mental effort rating scale. Participants also indicated their mental effort for both legal interviews on a 9-point rating scale. This scale was used to measure the perceived cognitive load of the legal interview.

Motivation rating scale. In addition, participants indicated their motivation for both legal interviews in each phase on a 3-item, 7-point rating scale. Examples of items: "I was motivated to perform well on this task," "This task was interesting to me," "I put a lot of effort into coming up with the best possible solution."

Content complexity rating scale. Finally, participants indicated their perceived complexity of the content for both the fact-finding interview and the legal advice interview on a 9-point rating scale.

\section{Procedure}

Prospective participants were canvassed at all four institutions that were involved in the development of the materials. Information about the materials (e.g., learning objectives, required prior knowledge and skills, estimated study load per w'eek, arrangement of the materials, and hardware requirements, privacy information and agreements) could be consulted by participants before they took part in the experiment. Prospective participants were asked to fill in and return the background questionnaire. For practical reasons, not all students showing interest could participate in the study, primarily as the course team preferred an approximately equal distribution of participants across all four institutions and also due to budget limitations. At each institution, date of showing interest was used as decision criterion. Subsequently, at each institution, participants were randomly assigned to one of the two experimental groups and were required to work individually. After studying the interviewing theory, participants were expected to work on the legal interview tasks. Participants working with the Multimedia Practical were strongly advised to work phase-by-phase because the program offered the possibility of skipping consecutive phases. Reported "time on task" values indicate that such participants did not skip any phases. Within a phase, there was maximum learner control so that participants were free to decide if and when to consult phase-specific information and how long to work on the assignment in a phase.

After six weeks (approximately 40 study hours), participants were required to carry out their prepared legal interviews at two different time slots (fact-finding, legal advice) during a one-day face to face session. Both legal interviews took place with a client and in front of two judges and as a result, the participants did not attend each other's legal interviews. The 
client role was played by several persons, each in advance receiving the same strict role description as well as the complete manuscripts as they were used in the recordings for the "interview simulator." There were strict time constraints for the interviews. During the last five minutes of a time slot, both judges briefly discussed participants' legal interviewing performance. But, before doing so, both judges independently scored the legal interview using the corresponding performance measurement. The interviews were videotaped for later evaluation, so that if the performance measurement instruments had proven neither reliable nor content-valid, then the performance was not lost. Participants were required to return the time sheet, and rating scales in a stamped self-addressed envelope. Participants were informed whether they did or did not earn the study/ course credits and received a monetary remuneration after completion of the material. This is a common procedure during testing of newly developed materials.

\section{Data analysis and scoring}

Two judges blindly and independently scored all participants' legal interviews using the performance measurement instruments. All efficiency measures were calculated using a procedure described by Pas and van Merriënboer $(1993)^{21}$ for determining instructional condition efficiency $(E)$.

\section{Results}

The collected data for determining computer literacy and attitude towards learning with computers showed no differences between the two groups. Remember that none of the participants had had prior legal interviewing experience (information derived from the collated background questionnaire data); and the randomised setup of this study ruled out the possible effect of domain knowledge. However, as university students can be expected to have more sophisticated academic skills than college students, students' educational background (university, college/high school) was treated as a covariate in all analyses.

\section{Performance}

The mean perform, legal advice interv significant effect $\mathrm{f}_{\mathrm{t}}$ interview. ANCOV performance of th $p<0.001, \quad \eta^{2}=0.2$ significantly outpr ( $\max =10)$. Univers students $(M=5.90$ $\eta^{2}=0.25$.

Table 1. Performa intervien

Fact-finding intervie task (1-10)

Legal adrice intervi task (1-10)

Fact-finding intervie task (1-10)

Legal advice interviє task (1-10)

${ }^{* *} p<0.001$ for availability 
lvance receiving the nanuscripts as they r." There were strict e minutes of a time legal interviewing endently scored the measurement. The $t$ if the performance ? nor content-valid, quired to return the ddressed envelope. lot earn the study/ after completion of testing of newly

participants' legal vents. All efficiency 1 by Paas and van ion efficiency $(E)$.

id attitude towards in the two groups. legal interviewing ound questionnaire $t$ the possible effect can be expected to students, students' ) was treated as a
Performance

The mean performance results for the legal fact-finding interview and the legal advice interview are summarised in Table 1. ANCOVA revealed no significant effect for the results on the performance of the fact-finding interview: ANCOVA revealed a significant effect for support on the performance of the legal advice interview $F(2,28)=6.43, \mathrm{MSE}=0.83$, $p<0.001, \quad \eta^{2}=0.34$. The experimental group $(M=7.29, \quad \mathrm{SD}=0.99)$ significantly outperformed the control group $(M=6.43, \quad \mathrm{SD}=1.13)$ ( $\max =10)$. University students $(M=7.23, \mathrm{SD}=0.83)$ outperformed college students $(M=5.90, \quad \mathrm{SD}=1.39), \quad F(1,28)=8.21, \quad \mathrm{MSE}=0.83, \quad p<0.001$, $\eta^{2}=0.25$.

Table 1. Performance on fact-finding interviewing task, and legal advice interviewing task

\begin{tabular}{lllll}
\hline & \multicolumn{3}{c}{ Support (manipulation variable) } \\
\cline { 2 - 5 } & \multicolumn{2}{c}{ No support $(n=7)$} & \multicolumn{2}{c}{ Support $(n=21)$} \\
\cline { 2 - 5 } & $M$ & SD & $M$ & SD \\
\hline $\begin{array}{l}\text { Fact-finding interviewing } \\
\text { task (1-10) }\end{array}$ & 7.50 & 1.19 & 7.29 & 1.18 \\
$\begin{array}{l}\text { Legal advice interviewing } \\
\text { task (1-10) }\end{array}$ & 6.43 & 1.13 & $7.29^{* *}$ & 0.99 \\
\hline
\end{tabular}

Participants' institution (covariable)

\begin{tabular}{lllll} 
& \multicolumn{2}{l}{ University $(n=23)$} & \multicolumn{2}{l}{ College $(n=5)$} \\
\cline { 2 - 5 } & $M$ & SD & $M$ & SD \\
\hline $\begin{array}{l}\text { Fact-finding interviewing } \\
\text { task (1-10) }\end{array}$ & 7.24 & 1.17 & 7.80 & 1.15 \\
$\begin{array}{l}\text { Legal advice interviewing } \\
\text { task }(1-10)\end{array}$ & 7.33 & 0.83 & 5.90 & 1.39 \\
\hline$x p<0.001$ for availability of support. & & & & \\
\hline
\end{tabular}


Time on task, mental effort, and motization

The mean results for time on task, mental effort, and motivation are summarised in Table 2.

Table 2. Time on task (in minutes), mental effort and motivation on fact-finding interviewing task, and legal advice interviewing task

\begin{tabular}{lllll}
\hline & \multicolumn{4}{c}{ Support (manipulation variable) } \\
\cline { 2 - 5 } & No Support $(n=7)$ & Support $(n=21)$ \\
\cline { 2 - 5 } & $M$ & SD & $M$ & SD \\
\hline Fact-finding interviewing task & & & & \\
Time on task & 306 & 149 & 416 & 216 \\
Mental effort (1-9) & 5.14 & 2.19 & 5.48 & 2.18 \\
Motivation (1-7) & 5.57 & 0.50 & 5.87 & 0.77 \\
Legal advice interviewing task & & & & \\
Time on task & 306 & 149 & 620 & 394 \\
Mental effort (1-9) & 7.00 & 1.00 & 6.29 & 2.5 \\
Motivation (1-7) & 5.62 & 0.68 & 5.89 & 0.76 \\
\hline
\end{tabular}

\section{Participants' institution (covariable)}

\begin{tabular}{lllll} 
& \multicolumn{2}{c}{ University $(n=23)$} & \multicolumn{2}{c}{ College $(n=5)$} \\
\cline { 2 - 5 } & $M$ & SD & $M$ & SD \\
\hline Fact-finding interviewing task & & & & \\
$\quad$ Time on task & 406 & 220 & 369 & 77 \\
$\quad$ Mental effort (1-9) & 5.61 & 2.21 & 4.40 & 1.67 \\
Motivation (1-7) & 5.80 & 0.70 & 5.80 & 0.87 \\
Legal advice interviewing task & & & & \\
$\quad$ Time on task & 408 & 233 & 373 & 107 \\
Mental effort (1-9) & 6.17 & 1.92 & 7.80 & 0.45 \\
Motivation (1-7) & 5.90 & 0.72 & 5.47 & 0.77 \\
\hline
\end{tabular}

Notes: Time on task based upon self-report.

Mental effort was measured on a 9 point rating scale ( $1=$ verv, very low mental effort, $9=$ very, very high mental effort).

Motivation was measured on a 3-item 7 point rating scale (Maynard and Hakel, 1997) (1=very, very low motivation, $7=$ very, very high motivation)

Source: F Paas, J.J.G. van Merriënboer and J.J. Adam, Measurenent of cognitive load in instructional research. Perieftunl anit Motor Skills, 79, 419-130 (1994).

D.C. Maynard and M.D. Hakel, Effects of objective and subjective task complexity on performance. Humim Prtfomance, 10(4), 303-330 (1997).
With regard to $b$ on task, mental effor

Participants repor $7.00(\max =9)$ for $b$ control groups. Part working on both between 5.57 and $5 . \varepsilon$

Task efficiency

The mean efficiency Table 3. Efficiency $w$ and $M=$ mental effor (the total mean was by the standard devi

Table 3. Efficiency interview

Fact-finding interviev Legal advice intervie

Fact-finding interview Legal advice intervier

${ }^{*} p<0.01$ for availability of ${ }^{* *} p<0.01$ for covariable $" p$

With regard to ta support on the effici covariable of the part Both groups were eq interviewing task a si $p<0.01, \eta^{2}=0.38$. T efficient than the $\mathrm{cc}$ 
and motivation are

and motivation on Idvice interviewing

\begin{tabular}{ll}
\hline \multicolumn{3}{l}{ thion variable) } \\
\hline 3upport $(n=21)$ \\
\hline 4 & SD \\
\hline & \\
16 & 216 \\
.48 & 2.18 \\
.87 & 0.77 \\
& \\
20 & 394 \\
.29 & 2.5 \\
.89 & 0.76 \\
\hline
\end{tabular}

ion (covariable)

$\frac{\text { ollege }(n=5)}{4 \quad \mathrm{SD}}$

69

.40

.80

73

.8

.4

$N$ mental effort, $9=$ very

d Hakel, 1997) (1= very:

it of cognitive load in

re task complexity on
With regard to both legal interview's, no significant differences for time on task, mental effort and motivation were found for ANCOVA's.

Participants reported an average mental effort, ranging between 5.14 and $7.00(\max =9)$ for both legal interviewing tasks in both experimental and control groups. Participants in both groups were highly motivated when working on both interviewing tasks, with motivation scores ranging between 5.57 and $5.89(\max =7)$.

\section{Task efficiency}

The mean efficiency results for both interviewing tasks are summarised in Table 3. Efficiency was calculated as $(P-M) / \mathrm{v}(2)$, where $P=$ performance, and $M=$ mental effort. The $P$ and $M$ scores on all variables are standardised (the total mean was subtracted from each score and the result was divided by the standard deviation), giving z-scores for each variable.

Table 3. Efficiency of fact-finding interviewing task and legal advice interviewing task

\begin{tabular}{lcccc}
\hline & \multicolumn{4}{c}{ Support (manipulation variable) } \\
\cline { 2 - 5 } & No Support $(n=7)$ & Support $(n=21)$ \\
\cline { 2 - 5 } & $M$ & SD & $M$ & SD \\
\hline Fact-finding interviewing task & 0.22 & 1.73 & -0.08 & 1.63 \\
Legal advice interviewing task & -0.72 & 1.10 & $0.24^{*}$ & 1.23 \\
\hline
\end{tabular}

Participants' institution (covariable)

\begin{tabular}{lllll} 
& \multicolumn{2}{c}{ University $(n=23)$} & \multicolumn{2}{c}{ College $(n=5)$} \\
\cline { 2 - 5 } & $M$ & SD & $M$ & SD \\
\hline Fact-finding interviewing task & -0.17 & 1.68 & 0.78 & 1.21 \\
Legal advice interviewing task & $0.32^{* *}$ & 1.09 & -1.49 & 0.84 \\
\hline
\end{tabular}

$* p<0.01$ for availability of support.

** $p<0.01$ for covariable "participants" institution.

With regard to task efficiency, ANCOVA did not reveal an effect for support on the efficiency of the legal fact-finding interviewing task. The covariable of the participants' institution did also not account for an effect. Both groups were equally efficient. ANCOVA revealed for the legal advice interviewing task a significant effect for support, $F(2,28)=7.69, \mathrm{MSE}=1.05$, $p<0.01, \eta^{2}=0.38$. The experimental group $(M=0.24, \mathrm{SD}=1.23)$ was more efficient than the control group $(M=-0.72, \mathrm{SD}=1.10)$, and university 
students $(M=-0.32, \mathrm{SD}=1.09)$ were more efficient than college students $(M=-1.49, \mathrm{SD}=0.84)$ in the legal advice interviewing task, $F(1$, 28) $=10.83, M S E=1.05, p<0.01, \eta^{2}=0.30$.

\section{Content complexity}

With regard to the complexity of the content for the fact-finding interview and the legal advice interview, as this was perceived by the participants, ANCOVA did not reveal a significant effect between experimental and control groups, nor did college students perceive the content complexity differently from university students (see Table 4).

Table 4. Content complexity of fact-finding interviewing case and legal advice interviewing case

\begin{tabular}{lllll}
\hline & \multicolumn{4}{c}{ Support (manipulation variable) } \\
\cline { 2 - 5 } & No Support $(n=7)$ & Support $(n=21)$ \\
\cline { 2 - 5 } & $M$ & SD & $M$ & SD \\
\hline Fact-finding interviewing case & 4.57 & 1.27 & 4.90 & 1.48 \\
Legal advice interviewing case & 6.86 & 0.69 & 6.14 & 1.42 \\
\hline
\end{tabular}

Participants' institution (covariable)

\begin{tabular}{lllll} 
& \multicolumn{2}{l}{ University $(n=23)$} & \multicolumn{2}{l}{ College $(n=5)$} \\
\cline { 2 - 5 } & $M$ & SD & $M$ & SD \\
\hline Fact-finding interviewing case & 4.91 & 1.35 & 4.40 & 1.82 \\
Legal advice interviewing case & 6.22 & 1.38 & 6.80 & 0.84 \\
\hline
\end{tabular}

Note: Content complexity is measured on a 9 -point rating scale $(1=$ very, very easy, $9=$ very, very difficult).

\section{Discussion}

This study examined the effect of support on both task performance and task efficiency. The results have shown that in the legal advice interviewing task, the experimental group out-performed the control group and was also more efficient. There were no differences between the two groups in their performance and efficiency with respect to the legal fact-finding interviewing task. Providing support in learning to solve complex whole tasks led to both higher performance and greater efficiency.

The finding that performance and efficiency in the legal fact-finding interview did not differ between the groups probably stems from the fact that, oddly enough, it was a disadiantage for the participants of the experimental group to "act" as if it was Several participants after the interview $t$ was too much supf the fact-finding inte indicates that too $\mathrm{n}$ learning. ${ }^{22}$

University stude legal advice intervi complexity between the students, the di skills. University s capabilities and may students. ${ }^{23}$ As a $f_{a}$ skills than an adv significant difference college students in $\mathrm{tl}$

A straightforward support offered witk acquiring complex sample sizes on the needed to make sucl learning would nee sample sizes may learning results. In transfer claim, but s in the learning mate yet be any measurab

The multimedia $F$ learning and face-to small course in itsel the world of legal i skills learning. But drawbacks in using embed the Practical i acquisition of legal determine how it wi

22 R. I. Vadolski, P. A. Kire learning tasks for compl

$23 \mathrm{C}$. Coles, and H. A. Hol Coles, and $\mathrm{H}$. A. Holn Press: Oslo (1993).

24 Paas and van Merrientro 
han college students riewing task, $F(1$.

act-finding interview by the participants, $\mathrm{n}$ experimental and content complexity

wing case and legal

\begin{tabular}{|c|c|}
\hline \multicolumn{2}{|c|}{ ation variable) } \\
\hline \multicolumn{2}{|c|}{ Support $(n=21)$} \\
\hline И & $\mathrm{SD}$ \\
\hline 1.90 & 1.48 \\
\hline .14 & 1.42 \\
\hline \multicolumn{2}{|c|}{ ion (covariable) } \\
\hline \multicolumn{2}{|c|}{ ollege $(n=5)$} \\
\hline 1 & SD \\
\hline 40 & 1.82 \\
\hline 80 & 0.84 \\
\hline
\end{tabular}

very easy: $9=$ v'ery very

performance and tvice interviewing oup and was also 'o groups in their legal fact-finding e complex whole ?.

legal fact-finding ms from the fact rticipants of the

experimental group to be prepared on this interview. As a result, they had to "act" as if it was the first time they were confronted with the content Several participants of the experimental group mentioned this difficulty after the interview to the judges. A second explanation could be that there was too much support for the participants of the experimental group for the fact-finding interview task. We have done some previous research that indicates that too much support as well as too little support can hinder learning. ${ }^{22}$

University students were more efficient than college students on the legal advice interview. As there is no significant difference in content complexity between university and college students as it was perceived by the students, the difference is probably rooted in differences of academic skills. University students may have better general problem-solving capabilities and may adapt faster to new situations in comparison to college students. ${ }^{23}$ As a fact-finding interview generally involves less academic skills than an advice interview this may explain why there was no significant differences in the efficiency and performance of university and college students in the fact-finding interview.

A straightforward practical implication of this study is that the kind of support offered within Multimedia Practicals is essential and sufficient for acquiring complex cognitive skills. Of course, more research with larger sample sizes on the circumstances and different formats of support is still needed to make such generalisations. In particular, the claim for transfer of learning would need to be explicitly tested. For example, using larger sample sizes may reveal time on task as a confounding variable for learning results. In the present study, there was no explicit testing of the transfer claim, but since there were only limited opportunities for practice in the learning materials, it was reasonable to expect that there would not yet be any measurable transfer effects. ${ }^{2+}$

The multimedia practical Legally Speaking can be used for both distance learning and face-to-face learning. It can be followed as an independent small course in itself, but then it will be no more than an introduction to the world of legal interviewing, because frequent practice is essential for skills learning. But we should recognise that there are of course also drawbacks in using ICT; and therefore it would probably be sensible to embed the Practical in a course that aims to support the student in the real acquisition of legal interviewing skills. However, an institution is free to determine how it will use the Practical withm its educational setting. For

\footnotetext{
22 R. I. Nadolshi. P. A. Kirsthner, and J. ]. G van Merrienboer. Optimising the number ris steps in

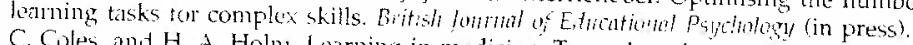

23 C. Coles, and H. A. Holn Learning in medicine: Tuwants a theory it medical education. ln $_{0}$. Coles, and H. A. Holm (Eds). Lentims a Natione, Fp. 189-209, Scandinavian Liniversity 24 Paas and van Merrienboer (144i); Spiru of $n$ l. (1988)
} 
effective use of such a resource, we recommend ${ }^{25}$ that students first work with the Practical, then conduct prepared legal interviews outside the Multimedia Practical ${ }_{r}$ in an actual simulated lawyer's office. ${ }^{26}$ The big advantage of such a Multimedia Practical is that students can prepare the Practical individually, without the support of a teacher, at their own speed and their own place and time. A Multimedia Practical helps to minimize the support of a teacher in face-to-face training and reduces the costs of such training. However, for really effective learning in this domain, it is necessary for students to experience a real-time interview, for three reasons. First, additional training in a face-to-face setting involves students more than a Multimedia Practical can do. Second, such situations allow for personalised feedback to individual students, which is not feasible within a Multimedia Practical. Third, assessment of the mastery of such a complex skill is not easy and involves natural persons in carrying it out. One has to develop clear and easy-to-use measurement instruments for the assessment of complex skills such as pleading, writing an essay, or interviewing. Considerable effort is needed to arrive at well-defined, unambiguous criteria. In addition, assessors require training in applying assessment instruments before actually using them.

Although ICT has some drawbacks, it also has interesting potential for development. Agent technology such as avatars might make more efficient electronic communication possible. Furthermore this technology also overcomes one of the bottlenecks of ICT programmes as it can provide more personalised adapted support, in a way similar to Intelligent Tutoring Systems. Another way of dealing with the high cost of tutor time is to use electronic communication facilities where more advanced students could play an important role in providing support to less experienced students. Distributed learning environments can benefit from generic support tools and offer life-long learners large-scale yet cost-effective adaptive e-learning environments for the acquisition of legal skills.

\section{Acknowledgements}

The authors would like to thank the anonymous law students from various Dutch institutions for their participation in this study and their teachers for letting them participate.

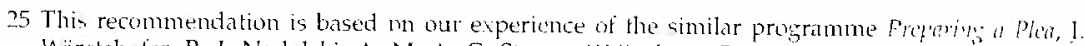
Wöretshifer, R. I. Natulski, A. M. A. G. Starren-Weijenbers, R. A. M. Quanjel-Schreurs, C. W. M. Aretz, N. H. W. van der Mees, G. Martyn, H. J. van den Brink, A. Slowmaker and I.

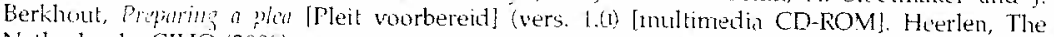
Netherlands: $\mathrm{CIHO}(2000)$.

26 This recommentation is based on our experience of the similin programme prepring of fied, 1 . Würetshnter, R.]. Natolskir A.M.A.G. St,arren-Weijenberg, R.A.M. Quanje-Schreurs, C.W.M. Aretz, N.H.W van der Moer G. Martyn, H.I. an den Brmk, A. Slowtnaker and J. Berkhut, Friporing of fin [Pleit vorbereid] (vers. 1.0 [nultimedia CD-ROM]. Herlen, The Netherlands: $\mathrm{CIHO}(2000)$. 